http://dx.doi.org/10.11646/phytotaxa.144.2.3

\title{
Neomillspaughia hondurensis (Polygonaceae), a new species from Central America
}

\author{
JUAN JAVIER ORTIZ-DÍAZ ${ }^{1 *}$, ITZIAR ARNELAS ${ }^{1}$, JUAN TUN $^{1} \&$ JOSÉ SALVADOR FLORES $^{1}$ \\ 1 Cuerpo Académico Diversidad de los Recursos Florísticos de Mesoamérica, Campus de Ciencias Biológicas y Agropecuarias, \\ Universidad Autónoma de Yucatán. A. P. 4-116, Mérida, Yucatán, México; odiaz@uady.mx \\ " author for correspondence
}

\begin{abstract}
A new species Neomillspaughia hondurensis (Polygonaceae) from Honduras is described and illustrated. This species is morphologically and ecollogicaly different from the other two currently known Neomillspaughia species, being more related to $N$. emarginata than to $N$. paniculata. A comprehensive comparison and a key for the three species are provided.
\end{abstract}

\section{Resumen}

Se describe e ilustra la nueva especie Neomillspaughia hondurensis (Polygonaceae) de Honduras. Esta especie es morfológicamente y ecológicamente diferente de las dos únicas especies de Neomillspaughia, estando más relacionada con $N$. emarginata que con $N$. paniculata. Se proporciona información comparativa de la nueva especie con las especies relacionadas y una clave para la identificación de las mismas.

Key words: Central America, Neomillspaughia, taxonomy

\section{Introduction}

Neomillspaughia S.F.Blake (1921: 84) is a genus of small trees restricted to dry forests of Central America (Burke et al. 2010) including two species: N. emarginata (H.Gross 1913: 218) S.F.Blake (1921: 85) distributed from Mexico (Yucatan Peninsula) to Belize and Guatemala, and N. paniculata (Donnell Smith 1899: 440) S.F.Blake (1921: 85) distributed from Guatemala, to Honduras and Nicaragua. Recent phylogenetic studies have clarified the position of $N$. emarginata as sister to Coccoloba P.Browne (1756: 209) (Burke et al. 2010, Burke \& Sánchez 2011). From the morphological point of view, Neomillspaughia is characterized by a winged 5-lobed perianth, peduncles without wings, pubescent filaments, and trigonous achene with acrescent tepals (Standley \& Steyermark 1946, Ortiz-Díaz 1994).

During the revision of herbarium material for the taxonomic treatment of Neomillspaughia for Flora Mesoamericana, we initially realized that some populations from Honduras showed inconsistencies in size and shape of the leaves, perianth, and fruit. After comparing, and measuring all available specimens we confirm that character variability did not fit the current morphological circumscriptions of any of the two already known species of Neomillspaughia, so we decided that it was a new one, here named as $N$. hondurensis. Previous collections of the new species were doubtfully identified as $N$. paniculata, but a detailed morphological examination revealed that the new species is more closely related to $N$. emarginata. In order to clarify the taxonomic status of $N$. hondurensis, a morphological and ecological study was carried out. 
TABLE 1. Principal taxonomic characters for the delimitation of the taxa (in fruit, measurements of the perianth length without pedicels).

\begin{tabular}{llll}
\hline & \multicolumn{1}{c}{ N. hondurensis } & \multicolumn{1}{c}{ N. emarginata } & \multicolumn{1}{c}{ N. paniculata } \\
\hline Apex of the leaf $(\mathrm{mm})$ & $10-16$ & $5-25$ & $25-40(-50)$ \\
Internodes width $(\mathrm{mm})$ & $2-3.5$ & $2-3.5$ & $3.5-4.5(-6.5)$ \\
Leaf blades $(\mathrm{cm})$ & $8-12 \times 8-10$ & $6-13 \times 6-14$ & $10-20(-30) \times 14-20(-30)$ \\
Petiole $(\mathrm{mm})$ & $20-30 \times 1-2$ & $19-30(-40) \times 1-2(-3)$ & $(20-) 30-40(-50) \times(1.5-) 2-3$ \\
& $7-13 \times 2-7$ & $8-10(-17) \times 8-15(-20)$ & $(10-) 13-20 \times 11-26$ \\
Inflorescence $(\mathrm{cm})$ & $1-3$ racemes with a rachis & $(3-) 6-10$ racemes with a & $5-12$ racemes with a rachis well \\
& not well differentiated & rachis well differentiated & differentiated \\
Perianth $(\mathrm{mm})$ & $10-14 \times 5-6$ & $8-11(-13) \times 4-5(-6.5)$ & $7-8(-10) \times 3-4(-4.8)$ \\
Inner tepals $(\mathrm{mm})$ & $3.5-4.0 \times 1.7$ & $2.5-3.5(-4.0) \times 2.0$ & $2.0-3.0 \times 0.8-1.0$ \\
Fruit $(\mathrm{mm})$ & $4.0-5.5 \times 2.5-3.5$ & $2.5-3.0(-4.0) \times 1.8-2.0$ & $2.5-3.5 \times 1.5-2$ \\
\hline
\end{tabular}

\section{Key to the species of Neomillspaughia from Mexico and Central America}

1. Leaf blades $14-20(-30) \mathrm{cm}$ width, emarginate at the apex $25-40(-50) \mathrm{mm}$; inflorescence $(10-) 13-20 \times 11-26 \mathrm{~cm}$ with a rachis of $2-3 \mathrm{~mm}$ width; perianth $7-8(-10) \times 3-4(-4.8) \mathrm{mm}$, inner tepals $0.8-1 \mathrm{~mm}$ width ...... N. paniculata

- Leaf blades 6-14 cm width, obtuse or emarginate at apex 5-25 mm; inflorescence 7-13(-17) $\times 2-15(-20) \mathrm{cm}$ with a rachis of $0.6-1.3 \mathrm{~mm}$ width; perianth $8-14 \times 4-6 \mathrm{~mm}$, inner tepals $1.7-2 \mathrm{~mm}$ width

2. Inflorescence a panicle with (3-)6-10 racemes in a rachis well differentiated, 8-15(-20) cm width; achene 2.5-3(4) $\times 1.8-2 \mathrm{~mm}$ N. emarginata

- Inflorescence a panicle with 1-3 racemes in a rachis not well differentiated, $2-7 \mathrm{~cm}$ width; achene 4.0-5.5 $\times 2.5-3.5$ $\mathrm{mm}$ N. hondurensis

\section{Acknowledgements}

We are grateful to the Director and Curators for the studied herbaria (BM, EAP, F, MO, NY, UADY, US). We appreciate helpful comments of anonimous reviewers. This work was partially financed by SEP-PROMEP "Fortalecimiento del Cuerpo Académico Diversidad de los Recursos Florísticos de Mesoamérica UADY-CA94". One of the authors, I. Arnelas Seco, was the beneficiary of a postdoctoral grant (ARNITZ81031712) financed by S.R.E. of Mexican Government.

\section{References}

Blake, S.F. (1921) Neomillspaughia, a new genus of Polygonaceae, with remarks on related genera. Bulletin of the Torrey Botanical Club 48: 77-88.

Browne, P. (1756) The Civil and Natural History of Jamaica in Three Parts. Gray's-Inn, London, 503 pp.

Burke, J.M, Sánchez, A., Kron, K. \& Luckow, M. (2010) Placing the woody tropical genera of Polygonaceae: a hypothesis of character evolution and phylogeny. American Journal of Botany 97(8): 1377-1390.

Burke, J.M, \& Sánchez, A. (2011) Revised subfamily classification for Polygonaceae, with a tribal classification for Eriogonoideae. Brittonia 63(4): 510-520.

Donnell Smith, J. (1899) Undescribed plants from Guatemala and other Central American Republics. XXI. Botanical Gazette 27(6): 434-443.

Gross, H. (1913) Th. Loesener. Mexicanische und zentralamerikanische Novitäte. IV. Repertorium specierum novarum regni vegetabilis 12: 217-244.

Ortiz-Díaz, J.J. (1994) Polygonaceae. Etnoflora Yucatenense 10. Universidad Autónoma de Yucatán. Mérida, 60 pp.

Standley, P. \& Steyermark, J. (1946) Flora of Guatemala. Fieldiana Botany 24: 122-123. 